Giovanni Ciotti

\title{
Notes for an Ontological Approach within Manuscript Studies: Object Oriented Ontology and the Pothi Manuscript Culture
}

\begin{abstract}
Defining a specific manuscript culture can be seen as an exercise in ontology. The present article embraces and applies the philosophical framework of object-oriented ontology (triple-O) as developed by the contemporary philosopher Graham Harman in order to appreciate what we can call the 'pothi manuscript culture'. As we acknowledge the existence of such a specific manuscript culture and the fact that it thrived for circa two millennia in South, South-East and Central Asia, we venture into identifying key historical moments and hypothesising possible counterfactual events that shaped it as a social object.
\end{abstract}

And as for those social theories that claim to avoid philosophy altogether, they invariably offer mediocre philosophies shrouded in the alibi of neutral empirical fieldwork.

(Harman 2016, 4)

Wer nichts über die Sache versteht, schreibt über die Methode.

(Gottfried Hermann, see Perilli 2006, 126)

\section{On the place of philosophy in manuscript studies}

The multifaceted field of manuscript studies combines a great variety of disciplines. Palaeography, codicology, philology, textual criticism, history, media studies, art history, archaeometry, book restoration and conservation, natural and computer sciences, and all the synergies and overlaps thereof contribute to the study of manuscripts, their contents and contexts. Potentially, all of these disciplines also intersect with philosophy, may it simply be for the fact that their practitioners should hopefully be reflecting on the theoretical underpinning and legitimacy of the methods they apply, or because philosophical concerns are essential parts of their discourse. However, to the best of my knowledge, a direct deployment of philosophy to the specific study of manuscript cultures is yet to be overtly explored. 
What follows is not more than a timid attempt at making a first step into this untrodden direction. In particular, we will apply one particular philosophical approach to the study of a specific manuscript culture, namely the 'pothi manuscript culture', so that we may be able to explore whether or not it is a thing (ontology) and how we can assess it (epistemology). Note that our intention here is not that of investigating what a 'pothi' is or what a 'manuscript culture' is, but that of studying through philosophical considerations a specific manuscript culture, in particular the one that has historically privileged pothis, as a legitimate social object. ${ }^{1}$

If one accepts some controversial - if not simply gross - labelling, among the several ramifications of that rabbit hole that is philosophy, we will plummet down the tunnel of 'continental philosophy', then, at the ensuing junction, further down that of 'speculative realism' and, finally, we will reach the theory commonly known as 'object-oriented ontology' (000, read 'triple-O'). Originally championed by a handful of contemporary philosophers, 000 calls for a renewed attention to objects in their own right.

Before delving further into the nitty-gritty of 000 and, in particular, the view articulated by Graham Harman, definitely its most well-known proponent, we must clarify from the start that our intent is not so much that of arguing in favour of the validity of this particular post-postmodernist move. Instead, we intend to experiment with 000 - out of the many available frameworks - and check whether it can help us open new avenues of inquiry in the field of manuscript studies. Harman has in fact already applied 000 to the field of social theory, in particular describing the Dutch East India Company (Vereenigde Oostindische Compagnie) and the American Civil War as objects. ${ }^{2}$

1 It should be made clear right off the bat that the term 'pothi' (pothī) is used here as an umbrella term for any manuscript that is made of a stack of folios in landscape format that are prepared for hosting writing and possibly illuminations and which are flipped upward rather than sideward. This term is here preferred to its Sanskrit etymological antecedent pustaka, or rather pustika, or to alternative terms in other languages simply for the sake of convenience, since it is widely understood by the community of scholars working on manuscripts from Central, South and South-East Asia.

2 See Harman 2016, 35-42 and Harman 2017, 114-134, respectively. 


\section{Ontology and epistemology: the case of 000}

In a nutshell, speculative realism is yet another reaction to Kant's 'thing-initself' (Ding an sich), one which claims that objects do exist outside our perception and that we can in fact say something about them. In Harman's take, objects cannot be directly (scientifically) known, but they can be indirectly (aesthetically) accessed. ${ }^{3}$

In order to understand how Harman can reach his theoretical stand, we first need to appreciate his definition of 'object'. As reiterated in many of his publications, an object is neither the sum of its parts nor that of its effects. In other words, on one side, Harman believes in the idea of emergence, i.e. that an object has properties that cannot be predicted from those of its components (which are in turn also objects!). For example, water has properties that cannot be predicted from those of hydrogen and oxygen when they are not combined. On another side, an object is not exhausted by its effects or actions, since it is also other than what it 'modifies, transforms, perturbs, or creates'. ${ }^{4}$ In fact, objects may have a potential that is only at times - or, even, never - expressed, such as the house-builder's ability to build a house even when asleep..$^{5}$

Harman is consistent with the logical consequences of this line of reasoning and calls object not only what is tangible, but also what is intangible, such as an event, a thought, a social construction. ${ }^{6}$ And since all these are equally objects in the definition posited by 000, Harman advocates as our philosophical starting point a 'flat ontology', in which all objects are treated on par with one another, with the consequence that also objects that are beyond human thought ought to be investigated. ${ }^{7}$ In any case, below we will apply this idea of object to

3 As it can be easily imagined, Harman's approach has attracted as much support as criticism. This is not the place to review the debate that ensued since 000 was proposed and references to the views opposing Harman's will be kept to the minimum.

4 This quotation is a paraphrase of a passage found in Bruno Latour's 1999 Pandora's Hope (p. 122), which Harman quotes rather often. The original passage is given in Harman 2016, 10.

5 This is in fact a reference to Aristotle's Metaphysics, see Harman 2017, 50. Approaches, such as OOO's, that 'ask us to personify and caricature objects as autonomous and alive' are clearly controversial and, it can be and has been argued, '[t]o adopt such a philosophy, no questions asked, is fantasy - commodity fetishism in academic form' (Cole 2015, online).

6 Note that Harman has explicitly stated that the existence of social objects is the most difficult to prove (<https://youtu.be/V3KMDy5gvwo, min. 1.26,40〉, accessed on 9 April 2021).

7 There are two main presuppositions characterising the approach championed by Harman and speculative realism in general. First, the shattering of the fetters of 'correlationism', a label coined by the contemporary philosopher Quentin Meillassoux (see Harman 2017, 56-57), 
the 'pothi manuscript culture', a social object which thus includes the human component by default. Following Harman's approach, we can already easily argue that our object of choice should not be seen as either the sum of its single manuscripts or reduced to the sum of its effects, such as helping the spread of Buddhism.

As Harman introduces his ontology, the question of epistemology inevitably arises and it is in this respect that we can perhaps better understand the point of his counter-Kantian approach mentioned at the beginning of this section. Rather persuasively, Harman maintains that scientific knowledge, as necessary and useful as it is, is a mere paraphrase of objects. Scientific knowledge, he argues, can either analyse something into its components or explain its functions. Instead, a gnoseological activity that can offer a different kind of knowledge is aesthetics, which has the power of evoking objects rather than analysing them. For example, a painting is more than the sum of its canvas, oilcolours, etc., and it is also not just the scene it represents, as any good art critic could tell us. In other words, scientific knowledge cannot get to objects per se, as they regress, escape from such kind of approach: we will never be able to appreciate the unexpressed potential of an object. However, objects can still be alluded to, evoked.

In this respect, a central role in Harman's theory - and a most crucial aspect for our current exercise - is played by metaphors. Harman's favourite is probably that of Homer's description of the sea as one 'wine-dark sea'. ${ }^{8}$ This is an allusion to properties of the sea that are not in plain sight, e.g. its ability to both intoxicate and exhilarate, and which emerge only when the sea is matched up with wine. This indirect, vicarious, evocative way of looking at objects is in fact the core of Harman's aesthetic epistemology. ${ }^{9}$

The question now is how do we move from metaphors as rhetorical means, i.e. our way of representing an encounter between objects, to metaphors as

which indicates the idea that objects can be accounted for only in terms of human perception. Then, as already mentioned, posing as our philosophical starting point a flat-ontology, i.e. 'an ontology that initially treats all objects in the same way' (Harman 2017, 54), a definition which in turn Harman takes from the work of another contemporary philosopher, Manuel DeLanda.

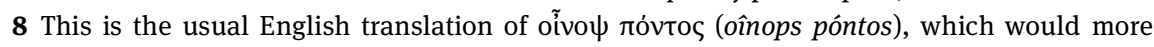
literally translate something like 'wine-faced sea'. However, it cannot be excluded that this was an actually perceived hue and thus that the metaphor would exist only in the English translation and not in the original Greek (cf. Deutscher 2010, 27-32; I would like to thank Aleix RuizFalqués for drawing my attention to this source). Even so, Harman's point would nevertheless hold.

9 A strong criticism to Harman's aesthetic turn can be found in Lemke 2017. 
social events, i.e. dynamics of actual encounters between objects? 000 maintains that our proverbial sea does not in fact meet the wine, but its dark quality and that this does not happen only at a fictional, literary level, but in reality, too, whenever objects meet. In other words, an object never meets another object, since objects infinitely regress from perception (nobody and nothing can really know the sea, whether the literal one or the real one, including its nonmanifest potential features), but only part of it, i.e. its tangible, manifest qualities ('sensual qualities' in Harman's lingo). ${ }^{10}$ Hence, like objects interact vicariously, so vicariously we can access objects.

Here finally comes what in my opinion is Harman's boldest methodological move: objects can be narrated metaphorically. This does not mean, however, that the narrative proceeds through a sequence of more or less convincing comparisons, but that it moves through the account of its metaphorical moments.

In Harman's view, such metaphorical moments are the turning points, the transformative encounters that change an object when it meets another object - or rather its qualities -, but that do not turn it into something new. In Harman's own words these moments are '[...] the key to unlocking a finite number of distinct phases in the life of the same object rather than the creation of a new one'. ${ }^{11}$ Particularly inspired by Lynn Margulis' work in the field of biology, Harman calls these metaphorical moments 'symbioses' - hereafter we will stick to this label - and defines them as 'a special type of relation that changes the reality of one of its relata, rather than merely resulting in discernible mutual impact'. ${ }^{12}$ From such a definition emerges an important characteristic of Harman's symbiosis, i.e. its non-reciprocal nature, since the two meeting objects are not equally affected by their encounter. ${ }^{13}$ If we return to Harman's favourite example, 'wine-dark sea' is not the same as 'sea-dark wine': to put it in banal terms, the former is enticing, the latter salty. All symbioses discussed below will exemplify this important non-reciprocal aspect.

A further characterising aspects of Harman's theory is that symbioses that did not take place are equally important, thus leading us into a sort of counterfactual

10 Harman 2017, 149-157. Note that this is a brutal condensation of the much more sophisticated view on objects and qualities proper to 000 .

11 Harman 2016, 49-50.

12 Harman 2016, 49. As for the equation metaphor symbiosis, in an interview from 2016 Harman rather explicitly stated that '[...] symbiosis is a metaphorical relation rather than a literal one [...]' (<http://badatsports.com/2016/in-the-late-afternoon-of-modernism-an-interviewwith-graham-harman/>, accessed on 9 April 2021).

13 Harman 2017, 112. 
history. ${ }^{14}$ For example, relevant to us is that the pothi form did not become part of the Turco-Persian material culture, ${ }^{15}$ a fact that may tell us about the maturity of the pothi manuscript culture at that moment in time, which prevented it from changing further.

As mentioned above, Harman has already offered symbiotic narratives of objects, in particular social objects. Hereafter, we will give it a try with the 'pothi manuscript culture'.

\section{0 and the pothi manuscript culture}

One 'pothi manuscript culture' is not defined as such by any of the learned traditions of South, South-East and Central Asia. But this does not make it less of an object in the frame of our current approach. Furthermore, a comprehensive history of the pothi manuscript culture that has extended across the geographical coordinates that we have just mentioned from at least the beginning of the common era well into the twentieth century is yet to be told. Until now, some scholars have opted, for example, for religious labels, such as Buddhist or Jain manuscript cultures, ${ }^{16}$ others have instead preferred geographical labels, such as South Asian or South Indian manuscript cultures, ${ }^{17}$ or linguistic ones, as in the case of Tamil or Pali manuscript cultures. ${ }^{18}$

In our view, it is likewise possible to argue in favour of the existence of a pothi manuscript culture and our ontological exercise is precisely aimed at appreciating this object, albeit vicariously. We should in fact emphasize that our understanding of what constitutes the pothi manuscript culture is not at all exhausted by the appreciation of the shared form of its artefacts, i.e. the stack of oblong writing surfaces. In the present context, the pothi manuscript culture is in fact more than the sum of its palms and their leaves; Himalayan birch (Betula utilis), agarwood tree (Aquilaria malaccensis) and their bark; its communities of tree-climbers, scribes, and scholars; its styluses, brushes, inks, and soot; its

14 Harman 2016, 116-117.

15 We prefer here the term 'form' instead of 'format', in accordance with a suggestion by the late J.P. Gumbert.

16 See, for instance, Berkwitz et al. 2009 and Balbir 2019, passim, respectively.

17 See, for instance, Shaw 2009, 127 and Rath 2012, respectively.

18 See, for instance, Sweetman and Ilakkuvan 2012, 19, and Ruiz-Falqués 2014, 30, respectively. One should note that, when it comes to labels such as 'Tibetan', 'Mongolian' or 'Thai', it is often unclear if these are meant to be geographical or linguistic. 
several dozens of languages and scripts; its conventions pertaining to writing, layout, and form; its texts, genres, and literary fashions; its courts, schools, monasteries, and temples; etc. Moreover, it would not be exhausted just by its manifest functions, such as enabling textual composition, transmission, and preservation; occupying generations of people working with palms and their products as well as hosts of more or less learned scholars and scribes; spreading Buddhism and Tantrism across Asia; etc.

Following Harman's methodology, before we look for possible symbioses in the history of the pothi manuscript culture, trying to map some of its turning points and missed opportunities, we first need to establish its beginning and end. In fact, as Harman states, '[i]f symbiotic stages are meant to mark discrete phases in the life of one and the same object, they must of course be distinguished from the birth and death of objects' ${ }^{19}$

\section{Beginning}

The beginning of a written tradition that made use of pothis is unknown. ${ }^{20} \mathrm{Nev}$ ertheless, it seems plausible to assume that such a culture began in the Indian subcontinent, when the leaves of certain palm trees, ${ }^{21}$ which are endemic to the southern part of that region, were first used as writing supports.

The oldest extant palm-leaf manuscripts, however, are not from South Asia but from Central Asia and the so-called 'Greater Gandhāra' (more or less corresponding to East Afghanistan and North Pakistan), where they could survive thanks to the dry climate, albeit mostly in an extremely fragmentary state. The earliest specimens found so far date to $c$. the second/third century CE. Two notable examples that have been dated on the basis of both palaeographical considerations and C-14 analysis are: 1 . the Spitzer manuscript dated to the third

19 Harman 2016, 50.

20 In this respect, see also Baums 2020, 349 n. 17. Reference to the oldest act of writing texts in manuscripts, which we may confidently assume were pothis, can be found in the Sri Lankan chronicle Dipavamsa (350 CE), which narrates how due to various calamities the Buddhist monks wrote down their sacred canon during the first century BCE (see Hartmann 2009, 96-97). Although one should not forget that probably oblong wooden tablets may also have been used for writing since time immemorial.

21 See below for more details on the kinds of palm trees employed. 
century $\mathrm{CE},{ }^{22}$ and 2. the Bamyan fragments of the Schøyen collection dated to the late second to the mid-third century $\mathrm{CE}_{.^{23}}$ Presumably, they had all been either directly produced in North India or manufactured on leaves imported from that region.

To this one should add that we have earlier oblong metal inscriptions, the shape of which suggests that the pothi form was already well known..$^{24}$ One example is the inscription on a gold leaf interred in a reliquary by King Senavarma of Odii, dated to the first half of the first century CE. ${ }^{25}$

As for South-East Asia, we do not have enough evidence to ascertain whether palm-leaf manuscripts had already existed in hoary times or they came through contacts with South Asia. ${ }^{26}$

But what do we exactly mean when we speak of 'palm-leaf'? This unspecific label is often used in catalogues and secondary literature to indicate the material of the manuscripts in question. However, more than one palm tree is used to obtain leaves that, once treated, can support writing: a fact that has more farreaching implications that one could at first think. Let us begin by pointing out that two palm trees that are endemic to South and South-East Asia are suitable for the production of manuscripts, namely Talipot (Corypha umbraculifera) and Palmyra (Borassus flabellifer). ${ }^{27}$

22 Franco 2004, 29, 32-33 maintains that on the basis of its script and content, the manuscript dates to the second half of the third century CE. As reported by Allon et al. 2006, C-14 places the manuscript within the date range $80-234 \mathrm{CE}$.

23 The dating is based on the results of carbon testing (Allon et al. 2006) and their combination with linguistic considerations (Salomon 2001 discussed in Salomon 2014, 6).

24 This observation was already made by Sircar 1965, 62.

25 See Baums 2012, 227-233.

26 The first mention of palm-leaf manuscripts from South-East Asia is found in the travel account of the Chinese official Zhou Daguan, who resided in Angkor between 1296 and 1297. He tells us that Cambodian monks used to read from manuscripts made of stacks of palm-leaves, on which they wrote without brush or ink (see Pelliot's 1902 translation; I would like to thank Volker Grabowsky for drawing my attention to this source).

27 Pace Hoernle 1901, who hypothesised that the Borassus flabellifer is of African origins. This theory persists in the literature, in particular in DNA studies of the Palmyra to explain the limited genetic difference that has been attested in these plants in both South India (George et al. 2016) and Thailand (Pipatchartlearnwong et al. 2017). However, botanical literature has shown that this hypothesis, if not completely disprovable, is certainly highly unlikely, owing to the morphological differences that characterise the Asian Borassus species from the African ones (see Bayton 2007 and Bellot et al. 2020). As for the limited DNA variation, this can be explained by the fact that the Asian Borassi speciated at a comparatively later stage. I would like to thank Ross P. Bayton for an illuminating email exchange (2 August 2020) on this topic. 
Using the leaves of these plants meant that manuscript production was part of a complex system of craftsmanship and commerce. In fact, Palmyra was not just used to produce writing supports, but was an essential good in South and South-East Asia, exploited for all sorts of practical usages: its wood for house and ship building; its fruits for edibles and drinks; its leaves for thatching roofs, manufacturing mats and bags, manuring rice fields; etc. ${ }^{28}$

On the other hand, it is plausible to assume that the leaves of Talipot enjoyed a certain prestige, thanks to their better quality in terms of texture, flexibility, and durability, thus making up for the otherwise limited application of the Talipot palm..$^{29}$ Allegedly, Talipot leaves were the only ones used for making pothi manuscripts in North India (and Central Asia) until the beginning of the seventeenth century. ${ }^{30}$

\section{End}

If the actual beginning of the pothi manuscript culture is beyond our reach due to the lack of material evidence, its end baffles us. The magnitude and complexity of its unfolding through time and space are among the reasons why a comprehensive and satisfactory account of the decline of the pothi manuscript culture is, I would argue, still a desideratum.

One could imagine that the introduction of new implements for the production of manuscripts or even the advent of altogether alternative technologies may have triggered its end. However, it is easy to disproof the idea of an abrupt

28 Ferguson 1888, 13-33 (note that the first edition dates back to 1850) offers a thorough account of the many uses of Palmyra in nineteenth-century Sri Lanka. A brief account concerning Tamil Nadu is found in Markham 1862, 428.

29 Apart from producing manuscripts, leaves of Talipot palms can be used for sheltering and thatching. See, for instance, Blatter 1926, 77-78.

30 Hoernle 1901. The results of Hoernle's survey need to be reassessed in the light of the many more manuscripts available in collections after more than a century from that study. However, if they were to still hold true, a new explanation of the absence of Palmyra leaves in manuscripts from North India (and Central Asia) - an absence that Hoernle thought was due to the late introduction of the Palmyra from Africa - would certainly be a topic worth investigating. For the sake of completeness, one should note that both the Spitzer manuscript and the Bamyan fragments of the Schøyen collection are made of Talipot leaves (see Franco 2004, 21 and Allon et al. 2006, 285, respectively). 
technological revolution: simply put, different artefacts just coexist. ${ }^{31}$ So it happened that pothis did not disappear when new supports became available, such as bark (e.g. from birch or agarwood) and paper, or the codex form was first met, or when different technologies (xylography and lithography) ${ }^{32}$ became available.

Even when printing with movable types arrived to India at the beginning of the sixteenth century with the Christian missionaries, ${ }^{33}$ it remained a niche technology until the nineteenth century. ${ }^{34}$ It is also remarkable that it did not even immediately obliterate the oblong form, which characterises some of the early prints in Calcutta. ${ }^{35}$

The fact remains that by the early twentieth-century pothi manuscripts as well as printed books in pothi form became rarer and rarer: a whole system of symbolic capital in which pothis played a role had in fact collapsed. The causes are many and their assessment still debated among scholars. We can mention, for example, 1. the loss of prestige on the part of the handwritten artefacts; ${ }^{36} 2$. a more impactful dissemination of the technology and craftsmanship required for printing with movable types $;{ }^{37}$ and 3. a new sociology of literate people, most of whom were eventually absorbed into the colonial administrative system and, thus, embraced its new book culture. ${ }^{38}$

31 A similar observation can be found for example in Diemberger et al. 2016, 6, where the similarities between the Tibetan and European cases are evoked, too.

32 Formigatti 2016, for xylography see also below.

33 Blackburn 2006, 30ff.

34 The same happened in South-East Asia, see Igunma 2013, 632-633.

35 See Rocher and Rocher 2012, 74.

36 Blackburn 2006, 35 maintains that Indians were not interested in print because they did not see any immediate advantage or prestige in the new technology.

37 Blackburn 2006, 35-36.

38 See O'Hanlon et al. 2020. A different narrative about the end of the manuscript culture in South Asia, but which overlaps with that of the end of the pothi manuscript culture, is offered by Pollock 2007, 87-90, who sees in the passage from manuscripts to print a shift from 'scriptmercantilism' (epitomised by Formigatti 2016, 112 as 'a typical feature of South Asian manuscript culture, consisting of its enormous productivity and efficiency, which led to the creation of a huge amount of manuscripts') to 'print-capitalism' (described by Pollock 2007, 91 as a the combination of 'the obliteration of oral text performance, the privatization of reading and the hyper-commodification of the book'). Formigatti 2016, 112-115 challenges Pollock's theory on several fronts and proposes a different narrative, according to which a blend of 'paper technology, Buddhism, and a centralized and strong state structure' (ibidem: 114) may have played a decisive role in ending the season of manuscripts, albeit concluding that the reason for the slow diffusion of print in all its forms still awaits to be fully appreciated. 
Pockets of pothi production as well as contemporary revivals thereof can be found everywhere in Central, South, and South-East Asia. ${ }^{39}$ Admittedly, this topic would deserve a broader investigation, but for now I would argue that these phenomena represent just a pale shadow of a culture that has lost its momentum and stamina.

\section{Symbioses}

We can now turn our attention to what are possible symbiotic moments in the history the pothi manuscript culture. Below I will argue that two symbioses occurred almost at the same time, albeit with distinguishable sets of consequences: on one side, the encounter with Himalayan birch and, on the other, the encounter with Buddhism. A further, yet later, symbiosis is then discussed, namely the encounter with xylography..$^{40}$

\subsection{Symbiosis 1: The encounter with Himalayan birch (or paper?)}

At an unspecified moment in the early common era, birch-bark pothis must have appeared from the encounter of communities of scribes and scholars that were familiar with both palm-leaf pothis and birch-bark craftsmanship - presumably including that for the production of the birch-bark scrolls of Greater Gandhāra, which contain the earliest recorded Buddhist scriptures and are attested from the first century BCE. ${ }^{41}$

39 For Tibet, in particular woodblock prints, see Almogi and Wangchuk 2016, 10; for Laos, see Igunma 2013, 631; for Bali, see van der Meij 2017, passim.

40 Not being able to access the very beginning of the pothi manuscript culture means we cannot access its initial symbioses either, which in Harman's view are the most characterising (Harman 2016, 118-119). The shift from orality to writing (on this topic in the Buddhist context, see references in De Simini 2016, 7-8), the encounter between materiality and specific literary genres (administrative literature, religious, didactic, etc.), the formation of a class of (professional?) scribes, the elaboration of Indic scripts, etc. are all inaccessible or only very partially accessible events to us, at least in terms that are beyond just those of reasonable assumptions.

41 On the mutual exchange that must have occurred between Buddhist Gandhāran communities familiar with birch-bark and immigrated Indian communities familiar with palm-leaves, see for instance Baums 2020, 358-359. On birch-bark scrolls, see e.g. Allon 2014, Baums 2014, Falk and Strauch 2014, and Salomon 2014. 
The oldest extant specimen of birch-bark pothi dates to the fifth century and hails from Central Asia, ${ }^{42}$ then we have the collections of birch-bark pothis from Gilgit and Bamyan (Greater Gandhāra), dating from the sixth to eighth century. ${ }^{43}$

We should briefly notice that, to my knowledge, we have three tiny extant fragments of paper manuscripts from Central Asia that date on palaeographical basis to the third/fourth century. ${ }^{44}$ Their extremely poor state of conservation seems to prevent an identification of their form, although, I would argue, pothi is a plausible option. ${ }^{45}$ Fortunately, however, we do have fragments of manuscripts made of silk, leather, and poplar wood palaeographically datable to $c$. the third century. ${ }^{46}$ One could therefore wonder if palm-leaf pothis encountered paper and other materials before birch-bark. I would tentatively argue that, on the basis of geographical considerations, it is more likely that the palmleaf pothi met Kashmirian birch before paper and other materials apparently used in Central Asia only, along the route from the Indian subcontinent to the oases of the Taklamakan Desert.

Notwithstanding what was the first alternative material, this encounter with a different writing surface constituted a symbiotic event for the pothi manuscript culture: its materiality deeply changed, since manuscripts could now be made with surfaces other than palm-leaves. ${ }^{47}$ It would probably be far-fetched to assume that this innovation directly opened the way for other materials to be used as writing surfaces, but we could definitely see it as the moment in which the latent adaptability of the pothi manuscript culture became manifest. We should not therefore be surprised that several other supports have been used through the regions of Central, South and South-East Asia to produce pothis. Apart from those already discussed above, we can also mention the leaves of

42 This is a copy of the Sanskrit treatise on metrics entitled Chandoviciti, discussed in Sander 1991, 137-138.

43 See Melzer 2014, 229 and Braarvig 2014, 158, respectively.

44 All three fragment contain small portions of texts written in Kharoșthī script: one is described in Conrady 1920, 113, 191, pl. 38, no. 36, and two in Hasuike 2004, 95-96, no. 6101 and 6102. Our source is Falk and Strauch 2014, 55, from which we report the date, although it should be noticed that Hasuike 2004, 95-96 proposes the fifth/sixth century as a date for the two fragments he describes.

45 A slightly later paper manuscript that is definitely in the pothi form and datable on a palaeographical basis to the fourth/fifth century is discussed in Hartmann 1988, 88-92.

46 For references, see Sander 1991, 147-148.

47 One could argue that we already have a change in materiality with metal inscriptions, such as those discussed above. However, several features of pothis are missing in inscriptions, such as the ink (whether liquid ink as in North India, or soot as in South India and South-East Asia) and the stack of folios to be turned upward. 
gebang palm (Corypha utan), which is another palm tree used in Indonesia, ${ }^{48}$ bark of agarwood in Assam, ${ }^{49}$ various kinds of paper in Central Asia and at later stages in Northern India, ${ }^{50}$ and sheets of metal, ivory, etc. as in the case of some particularly luxurious lacquered Kammavacas from Burma. ${ }^{51}$

Remarkably, on the basis of the extant material, what seems to have happened is that some birch-bark manuscripts dispensed with string-holes, ${ }^{52}$ contrary to the majority of birch-bark pothis, as well as palm-leaf pothis and the above-mentioned pothis made with paper, silk, leather, and poplar wood. ${ }^{53}$ Instead of holes, we find place holders, such as decorations or blank spaces. It is this the moment in which the unbound (or loosely bound) pothi makes its appearance, an innovation which will characterise virtually all subsequent North Indian paper as well as woodblock pothis ever produced..$^{54}$

On the other hand, and here lies the non-reciprocity of our current symbiosis, although the craftsmanship related to birch does change too, since its multipurpose bark-sheets became part of a further new economy, I do not think that this changed much the ecology of the tree, with presumably just a relatively small number of plants directly affected, i.e. those from which bark was extracted. Moreover, we do not know of birch undergoing domestication, i.e. it was not cultivated with the precise aim of providing writing surfaces, contrary for

48 See Gunawan 2015.

49 See Morey 2015.

50 For a recent assessment of the early history of paper in Central Asia, see Helman-Ważny 2020. For an overview of paper pothis from Dunhuang (datable to $c$. the eight century), which carry texts in both Tibetan and Chinese, the latter written either vertically or horizontally (left to right), see Galambos 2020, 25-27, 143-152. As for paper used for manuscripts in India we are told of a few dating to the eleventh to thirteenth century (Gode 1969, 7), although paper was known in India before, most probably since the seventh century as witnessed by the Chinese pilgrim Yijing during his travel to India and as we know from the analysis of the folios made of 'clay-coated paper' from Gilgit (for a recent account, see Scherrer-Schaub 2016, 154-155). Concerning the latter, we have three fragmentary manuscripts that contain folios made of both birch-bark and this rare material, as for example a copy of the Samghāțasūtra (von Hinüber 2014, 91, 104 and Kishore 1963).

51 See e.g. Igunma 2013, 632.

52 For example, we know of the Bakhshālī manuscript, which has no sting-holes, and whose folios are more squared than oblong and thus cannot be readily categorised as a pothi (for a reproduction, see Kaye 1927).

53 As mentioned above, the earliest exemplars of paper manuscripts are too fragmentary, but the paper pothi discussed by Hartmann definitely has holes (Hartmann 1988, 89). For descriptions and reproductions of the silk, leather, and poplar wood pothis, see Stein 1928a, 1024 and Stein 1928b, Plate CXXI, Lüders 1940, 586, and Nakatani 1987, respectively.

54 For a similar observation, see Hoernle 1901, 127-128. 
example to Talipot, which may have been cultivated with this purpose, as apparently witnessed in the seventh century by the Chinese pilgrim Xuanzang. ${ }^{55}$

\subsection{Symbiosis 2: Encounter with Buddhism}

The encounter with Buddhism, in particular its Mahāyāna version, had profound consequences for the pothi manuscript culture. Certainly, one of the most prominent is that pothis acquired sacral and ritualistic functions on top of their presumably practical ones (educational, administrative, etc.). They became objects of veneration, the production and reproduction of which was believed to have positive effects on the rebirth of donors and their families. ${ }^{56}$ The same practice was to be later adopted by certain strands of Brahmanism and Jainism, as well..$^{57}$

In the eyes of monks, nuns, and laypeople, manuscripts containing Buddhist texts (sūtras in particular) became tantamount to the Buddha's speech or even his body (inasmuch as they are equated to his relics), thus attaining a holy status. ${ }^{58}$ Such a status was accompanied by the development of ritualistic usages of manuscripts, in particular their being installed in stūpas or carried around as amulets. ${ }^{59}$

A further implication of the new status attributed to manuscripts was the development of the practice of vidyādāna ('gift of knowledge'): donating manuscripts as well as writing implements became a meritorious act. ${ }^{60} \mathrm{~A}$ sign of the far-reaching implications of this phenomenon is for example that, within the Indian context, even manuscripts containing Vedic texts were written down and donated ${ }^{61}$ despite the fact that the official voice of Brahmanism notoriously abhorred such a practice. ${ }^{62}$

55 See Hoernle 1901, 124.

56 For references, see De Simini 2016, 2-22.

57 See De Simini 2016 and Cort 1992, respectively.

58 These equations are still debated as far as early Mahāyāna Buddhism is concerned (see references in De Simini 2016, 8-11), but have later become well-established, as in the case of Tibetan Buddhism (Almogi and Wangchuk 2016, 5-7) and Mongolian Buddhism (Wallace 2009, 91).

59 For references, see De Simini 2016, 8-13.

60 De Simini 2016. The label vidyādanna is used here for the sake of convenience, although it is not used by all relevant sources.

61 Galewicz 2011.

62 Kane 1941, 348-349. 
Concerning the non-reciprocity of the current symbiosis, I would venture to argue that the fact of having its texts transmitted on codices, scrolls, or pothis did not make much of a difference for Buddhism. Those artefacts initially became sacred not for their shape, but for the texts they contained, even though out of habit the oblong shape ended up evoking a reaction of awe and respect in the people engaging with pothis.

\subsection{Symbiosis 3: Encounter with xylography}

A further symbiosis was triggered by the encounter with xylography, alias woodblock print, a technology originally developed in China, at least from the fifth century. ${ }^{63}$

For obvious geographical reasons, such encounter took place first in Central Asia. Camillo A. Formigatti has convincingly argued that the date of a specific woodblock printed pothi, namely item 612 (Samyuktāgama) of the Sanskrithandschriften aus den Turfanfunden, ranges between 850-1250, i.e. the Uighur occupation of the city of Qočo. ${ }^{64}$ However, we have so few extant materials from that area that it is probably easier to focus our attention on the spread of this technology in Tibet from the early fifteenth century onwards. ${ }^{65}$

The Tibetan case can help us find a way out of the debate whether such prints can still be considered manuscripts. Here, I would like to tackle this conundrum by arguing that, even if one wants to argue that individual artefacts cannot be counted as manuscripts, their production and perception can still be recognised as part of the pothi manuscript culture, just one that has changed owing to the encounter with xylography. ${ }^{66}$

Concerning the production aspect, we can mention, for example, the fact that xylography necessitates copyists who produce the manuscript that is then pasted on the woodblock, and thus perpetuates the habitus of handwriting, including its stylistic variations and orthographic mistakes, ${ }^{67}$ or that the scribe

63 Barret 2008, 67.

64 Formigatti 2016, 86, see also ibid. $81 \mathrm{n}$. 11 about the fragments of this specific pothi.

65 For the dating of early Tibetan woodblock prints, see e.g. Diemberger 2016.

66 We thus try to answer differently the question raised by Formigatti 2016, 118: '[...] xylographs and lithographs certainly aren't manuscripts, but should we still equate them to books printed with movable types and printing presses? Maybe it would be better to think of them as something similar to a manuscript and a printed book at the same time, and yet different from both'.

67 Scherrer-Schaub 2016, 166. 
of the manuscript can also be one of the craftsmen involved in the carving of woodblock..$^{68}$ Also in terms of layout, one can notice that, as in the case of certain birch-bark and paper pothis from North India, a placeholder for the stringhole is maintained also in the prints, further enhancing the idea of continuity with palm-leaf manuscripts. ${ }^{69}$ Concerning their perception one can mention that primary sources seem to rarely differentiate between manuscripts and prints, ${ }^{70}$ or that both artefacts are still produced in Tibet, since they are attributed an aura unmatched by other media, such as the modern printed book. ${ }^{71}$

As for the non-reciprocal aspect of the symbiosis in question, I would argue that xylographic technology did not really change when it encountered pothis, but that on the other hand the pothi manuscript culture significantly changed, yet without loosing its identity. As in the case of the adoption of birch-bark as a writing surface, xylography did not spread across the whole pothi manuscript culture, but yet revealed the potential of the latter to survive and incorporate technological innovations.

\section{A missed symbiosis}

We now turn to what seems to me to have been a rather conspicuous case of missed symbiosis, namely the lack of interaction between the pothi manuscript culture and the Turco-Persian culture.

Caveats are in place, as we will see below, we are talking here of the Islamic culture and political power that came to the Indian subcontinent along with the Turkic Islam of Central Asia (twelfth/thirteenth to sixteenth century) and, later on, the Turco-Persian Islam of the Mughals (from the sixteenth century) and not of Islam tout court. In fact, Islam and pothis, in particular palm-leaf ones, did meet, though the encounter never gained a strong momentum. We thus have palm-leaf pothis produced in the Tamil Muslim milieu and a certain Islamic tradition proper to the Sasak community of Lombok (Indonesia). ${ }^{72}$

68 Two such craftsmen, both active in the sixteenth century, are dPal ldan rgyal po (Ehrhard 2016, 219-220) and Ba dzra dho ja (Vajradhvaja) (Clemente 2017, 387-388).

69 Scherrer-Schaub 2016, 164-165.

70 Sharshon 2016, 238.

71 See Almogi and Wangchuk 2016, 10.

72 More 2004, 36-37 offers a succinct report of the former, whereas aspects of the latter are discussed in van der Meij forthcoming. Note that the same is true in the case of Christian literature in South India. One possible exception could be that of the Bengal pothis containing the 
On the other hand, we approach a statistical zero when we look for manuscripts in pothi form that contain Islamic texts belonging to Turco-Persian Islam. Within our approach, this does not mean, though, that the pothi manuscript culture is dormant or dead, but rather that by the time Islam enters the subcontinent from North-west, it has reached a maturity and a selfcontainedness that do not leave room for any symbiotic pulse. ${ }^{73}$ This non-event is particularly noteworthy given the otherwise astounding and variegated forms of Indo-Persian syncretism, ${ }^{74}$ and precisely because it is indirectly revealing of the nature of the pothi manuscript culture as an object $\grave{a}$ la 000 .

In contrast, we can observe how the Islamic codex culture is able to interact with local languages and materials. Thus, we see the production of codices containing texts composed in Sanskrit and various (Northern) Indian vernaculars, as well as guțakās, i.e. codices in landscape form which were used by Hindus, Sikhs, and Jains. ${ }^{75}$ Similarly, we have Hindu motives depicted on vertical, codex-like layout, e.g. in the paintings of the Mewar school by the artists Nasiruddin (sixteenth century) or Sahibdin (seventeenth century), ${ }^{76}$ but to the best of my knowledge no Islamic motives painted in the horizontal, pothi-like layout.

\section{Cui prodest?}

We have hopefully shown that Harman's approach may help us find a melody amidst the historiographical noise, in other words an ontology, by both highlighting a certain kind of key moments (symbioses) in the history of the pothi manuscript culture and speculating on missed events - in Harman's own terms: '[p]aradoxically, to show us what any object is in itself requires subtracting from the knowledge we have about it: focusing austerely on its essential features

deeds of pirs ('sufi masters'), such as the two copies on paper pothi of the Satya Pirrera Pāñ āli recorded by project EAP759 of the Endangered Archive Programme of the British Library (<https://eap.bl.uk/project/EAP759>, accessed on 9 April 2021), namely EAP759/1/4 and EAP759/1/90. However, since pirs are considered to be holy individuals also by the local Vaishnava communities, I would argue that the manuscripts in question are not the result of the Islamic appropriation of the pothi form, but rather of Islam entering the pothi form once it has been absorbed by Hinduism.

73 In Harman's words, an object is mature when '[a]ll that remains is for the object to capitalize on what it has become by feeding on its environment' (Harman 2017, 121).

74 For a recent survey of this multifarious encounter, see Eaton 2019.

75 See Formigatti 2020.

76 Guy and Britschgi 2011, 98-102. 
rather than promiscuously on all of them, and playing both counterfactually and poetically with other possible outcomes' ${ }^{77}$

In this respect, we argue that the angle offered by 000 on manuscript studies is fresh and productive. In particular, it is an approach that has allowed us to engage with a specific manuscript culture, whereas other approaches would have us ask different questions, such as what is $a$ manuscript or what is $a$ manuscript culture. Thus, we cannot but conclude by expressing the wish that others will further foster the interaction between the field of philosophy and that of manuscript studies, over which - we insist - the wings of Minerva's owl are not going to spread for a long time to come. ${ }^{78}$

\section{Acknowledgements}

I would like to thank Daniele Cuneo, Camillo A. Formigatti, Marco Franceschini, Volker Grabowsky, Jooyoung Lim, Aleix Ruiz-Falqués, Paolo Visigalli, Eva Wilden, Hanna Wimmer and an anonymous reviewer for carefully reading through early drafts of this paper and offering extremely valuable suggestions. Many thanks also go to Ross P. Bayton for answering my queries on the Borassus genus, and to Richard J. Gornall and Irina Wandrey for helping me access a number of publications. All mistakes and ravings are of course mine only.

\section{References}

Allon, Mark (2014), 'The Senior Kharoșțī Manuscripts', in Harrison and Hartmann (eds) 2014, 19-34.

Allon, Mark, Richard Salomon, Geraldine Jacobsen and Ugo Zoppi (2006), 'Radiocarbon Dating of Kharoșțhī Fragments from the Schøyen and Senior Manuscript Collections', in Jens Braarvig (ed.), Buddhist Manuscripts, vol. 3: Manuscripts in the Schøyen Collection, Oslo: Hermes Publishing, 279-291.

Almogi, Orna (ed.) (2016), Tibetan Manuscript and Xylograph Traditions: The Written Word and Its Media within the Tibetan Culture Sphere (Indian and Tibetan studies, 4), Hamburg: Department of Indian and Tibetan Studies, Universität Hamburg.

77 Harman 2019, 275. In a similar vein, while referring to the fact that printing did not have much of an impact in South Asia for a long time, Sheldon Pollock quotes Fernand Braudel's statement that “"civilisations” are defined as much by what they refuse from others as by what they borrow' (Pollock 2007, 87).

78 'Die Eule der Minerva beginnt erst mit der einbrechenden Dämmerung ihren Flug' (Hegel 1821, xxiv). 
Almogi, Orna and Dorji Wangchuk (2016), 'Prologue: Tibetan Textual Culture between Tradition and Modernity', in Almogi (ed.) 2016, 5-30.

Balbir, Nalini (2019), 'Functions of Multiple-Text Manuscripts in India: The Jain Case', in Alessandro Bausi, Michael Friedrich and Marilena Maniaci (eds), The Emergence of MultipleText Manuscripts (Studies in Manuscript Cultures, 17), Berlin: De Gruyter, 1-36.

Barrett, Timothy Hugh (2008), The Woman who Discovered Printing, New Haven, CT: Yale University Press.

Baums, Stefan (2012), 'Catalog and Revised Texts and Translations of Gandharan Reliquary Inscriptions', in David Jongeward, Elizabeth Errington, Richard Salomon and Stefan Baums (eds), Gandharan Buddhist Reliquaries (Gandharan Studies, 1), Seattle, WA: University of Washington Press, 200-309.

Baums, Stefan (2014), 'Gandhāran scrolls: Rediscovering an ancient manuscript type', in Quenzer, Bondarev and Sobisch (eds) 2014, 183-225.

Baums, Stefan (2020), 'Inventing the Pothi: The Adoption and Spread of a New Manuscript Format in Indian Buddhism', in Toke Lindegaard Knudsen, Jacob Schmidt-Madsen and Sara Speyer (eds), Body and Cosmos: Studies in Early Indian Medical and Astral Sciences in Honor of Kenneth G. Zysk (Sir Henry Wellcome Asian Series, 20), Leiden: Brill, 343-362.

Bayton, Ross P. (2007), 'A Revision of Borassus L. (Arecaceae)', Kew Bulletin, 62/4: 561-585.

Bellot, Sidonie, Ross P. Bayton, Thomas L. P. Couvreur, Steven Dodsworth, Wolf L. Eiserhardt, Maïté S. Guignard, Hugh W. Pritchard, Lucy Roberts, Peter E. Toorop, and William J. Baker (2020), 'On the origin of giant seeds: the macroevolution of the double coconut (Lodoicea maldivica) and its relatives (Borasseae, Arecaceae)', New Phytologist, 228/3: 1134-1148.

Berkwitz, Stephen C., Juliane Schober and Claudia Brown (eds) (2009), Buddhist Manuscript Cultures: Knowledge, Ritual, and Art, London: Routledge.

Blackburn, Stuart (2006), Print, Folklore, and Nationalism in Colonial South India, New Delhi: Permanent Black.

Blatter, Ethelbert (1926), The Palms of British India and Ceylon, London: Oxford University Press.

Braarvig, Jens (2014), 'The Schøyen Collection', in Harrison and Hartmann (eds) 2014, 157-164.

Clemente, Michela (2017), 'On a Particular Aspect of the Identification of Tibetan Xylographs: Preliminary Remarks on the Importance of Craftsmen', Kervan - International Journal of Afro-Asiatic Studies, 21: 373-394.

Cole, Andrew (2015), 'Those obscure objects of desire: The uses and abuses of object-oriented ontology and speculative realism', Artforum 53/10: <artforum.com/print/201506/theuses-and-abuses-of-object-oriented-ontology-and-speculative-realism-andrew-cole52280> (accessed on 9 April 2021).

Conrady, August (1920), Die chinesischen Handschriften und sonstigen Kleinfunde Sven Hedins in Lou-lan, Stockholm: Generalstabens Litografiska Anstalt.

Cort, John E. (1992), 'Śvetāmbar Mūrtipūjak Jain Scripture in a Performative Context', in Jeffrey R. Timm (ed.), Texts in Context: Traditional Hermeneutics in South Asia, Albany: State University of New York Press, 171-194.

De Simini, Florinda (2016), Of Gods and Books: Ritual and Knowledge Transmission in the Manuscript Cultures of Premodern India (Studies in manuscript cultures, 8), Berlin: De Gruyter.

Deutscher, Guy (2010), Through the Language Glass: Why the World Looks Different in Other Languages, New York: Metropolitan Books Henry Holt and Company. 
Diemberger, Hildegard (2016), 'Early Tibetan Printing in Southern La stod: Remarks on a 1407 Print Produced at Shel dkar', in Almogi (ed.) 2016, 105-125.

Diemberger, Hildegard, Franz-Karl Ehrhard and Peter Kornicki (eds) (2016), Tibetan printing: Comparisons, Continuities and Change (Brill's Tibetan Studies Library, 39), Leiden: Brill.

Eaton, Richard Maxwell (2019), India in the Persianate Age: 1000-1765, London: Penguin Books.

Ehrhard, Franz-Karl (2016), 'Collected Writings as Xylographs: Two Sets from the Bo dong pa School', in Diemberger, Ehrhard and Kornicki (eds) 2016, 212-236.

Falk, Harry and Ingo Strauch (2014), 'The Bajaur and Split Collections of Kharoșthī Manuscripts within the Context of Buddhist Gāndhārī Literature', in Harrison and Hartmann (eds) 2014, 51-78.

Ferguson, William (1888), Palmyra Palm: Borassus Flabelliformis [...], 2nd edn, Colombo: Ceylon Observer Press.

Formigatti, Camillo A. (2016), ‘A Forgotten Chapter in South Asian Book History? A Bird's Eye View of Sanskrit Print Culture', in Diemberger, Ehrhard and Kornicki (eds) 2016, 72-134.

Formigatti, Camillo A. (2020), 'Guțakās between Book Cultures. The Voelter Manuscripts in the Tübingen University Library’, in Heike Oberlin and Frank Köhler (eds), Die 1.000 Namen Vishnus. Vișṇusahasranāma. Sanskrit-Handschriften aus der Sammlung Heide und Wolfgang Voelter, Tübingen: Eberhard Karls Universität Tübingen, Museum der Universität Tübingen MUT, 64-90.

Franco, Eli (2004), The Spitzer Manuscript: The Oldest Philosophical Manuscript in Sanskrit (Beiträge zur Kultur- und Geistesgeschichte Asiens, 43; Denkschriften - Österreichische Akademie der Wissenschaften. Philosophisch-Historische Klasse, 323), vol. 1, Vienna: Verlag der österreichischen Akademie der Wissenschaften.

Galambos, Imre (2020), Dunhuang Manuscript Culture: End of the First Millennium (Studies in manuscript cultures, 22), Berlin: De Gruyter.

Galewicz, Cezary (2011), “'Let Śiva's favour be alike with scribes and with reciters”: Motifs for copying or not copying the Veda', in Travaux de Symposium International 'Le livre. La Roumanie. L'Europe'. Troisième édition - 20 à 24 Septembre 2010, vol. 3: La troisième section - Études euro- et afro-asiatiques, Bucarest: Bibliothèque de Bucarest, 113-146.

George, Jiji, K. T. Venkataramana, P. Nainar, M. K. Rajesh and Anitha Karun (2016), 'Evaluation of molecular diversity of ex situ conserved germplasm of palmyrah (Borassus flabellifer L.) accessions using RAPD markers', Journal of Plantation Crops, 44/2: 96-102.

Gode, P. K. (1969), 'Migration of paper from China to India-A.D. 105-1500', in Studies in Indian Cultural History (Vishveshvaranand Vedic Research Institute; Publications), vol. 3, Poona: Prof. P.K. Gode Collected Works Publication Committee, BORI, 1-12.

Gunawan, Aditia (2015), 'Nipah or Gebang? A Philological and Codicological Study Based on Sources from West Java'. Bijdragen tot de Taal-, Land- en Volkenkunde, 171/2,3: 249-280.

Guy, John and Jorrit Britschgi (2011), Wonder of the Age: Master Painters of India 1100-1900, New York:The Metropolitan Museum of Art.

Harman, Graham (2016), Immaterialism: Objects and social theory (Theory redux), Cambridge: Polity Press.

Harman, Graham (2017), Object-oriented ontology: A new theory of everything (Pelican book, 18), London: Pelican.

Harman, Graham (2019), 'The Coldness of Forgetting: 000 in Philosophy, Archaeology, and History’, Open Philosophy, 2/1: 270-279. 
Harrison, Paul and Jens-Uwe Hartmann (eds) (2014), From Birch Bark to Digital Data: Recent Advances in Buddhist Manuscript Research: Papers Presented at the Conference Indic Buddhist Manuscripts: The State of the Field. Stanford, June 15-19 2009 (Beiträge zur Kultur- und Geistesgeschichte Asiens, 80; Denkschriften - Österreichische Akademie der Wissenschaften. Philosophisch-Historische Klasse, 460), Vienna: Verlag der österreichischen Akademie der Wissenschaften.

Hartmann, Jens-Uwe (1988), 'Neue Aśvaghoșa- und Mātṛceța-Fragmente aus Ostturkistan', Nachrichten der Akademie der Wissenschaften in Göttingen aus dem Jahre 1988: Philologisch-Historische Klasse, 2: 53-92.

Hartmann, Jens-Uwe (2009), 'From words to books: Indian Buddhist manuscripts in the first millennium CE', in Berkwitz, Schober and Brown (eds) 2010, 95-105.

Hasuike, Toshitaka 蓮池利隆 (2004), 'Seiiki nandō to seiiki hokudō no karōshutī moji shiryō no hikaku'西域南道と西域北道のカローシュティー文字資料の比較, in Moriyasu Takao 森安孝夫 (ed.), Papers on the Pre-Islamic Documents and Other Materials Unearthed from Central Asia (Chūō ajia shutsudo bunbutsu ronsō, 中央アジア出土文物論叢), Kyoto: Hōyū shoten, 93-109.

Hegel, Georg Wilhelm Friedrich (1821), Grundlinien der Philosophie des Rechts, Berlin: In der Nicolaischen Buchhandlung.

Helman-Ważny, Agnieszka (2020), 'Notes on the early history of paper in Central Asia based on material evidence', in Agnieszka Helman-Ważny (ed.), Studies into the History of the Book and Book Collections, 14/3: Asian paper as writing support, Warsaw: University of Warsaw, 341-366.

Hoernle, A.F. Rudolf (1901), 'An Epigraphical Note on Palm-leaf, Paper and Birch-bark', Journal of the Asiatic Society of Bengal, LXIX, Part I (Histories, Antiquities, \&c.) (Nos. I and II.1900): 93-134.

Igunma, Jana (2013), 'The History of the Book in Southeast Asia (2): The Mainland', in Michael F. Suarez S.J. and H. R. Woudhuysen (eds), The book. A global history, Oxford: Oxford University Press, 629-634.

Kane, Pandurang Vaman (1941), History of Dharmaśāstra (Ancient and Mediaeval Religious and Civil Law), vol. 2/1, Pune: Bhandarkar Oriental Research Institute. Government Oriental Series.

Kaye, George Rusby (1927), The Bakhshālī manuscript: A study in mediæval mathematics, Calcutta: Government of India central publication branch.

Kishore, Ranbir (1963), 'A Clay-coated manuscript in the Gilgit collection', The Indian Archives, 15: 71-73.

Lemke, Thomas (2017), 'Materialism without matter: the recurrence of subjectivism in objectoriented ontology', Distinktion: Scandinavian Journal of Social Theory, 18/2: 133-152.

Lüders, Heinrich (1940), 'Medizinische Sanskrit-Texte aus Turkestan', in Philologica Indica: Ausgewählte kleine Schriften von Heinrich Lüders, Festgabe zum siebzigsten Geburtstage am 25. Juni 1939 dargebracht von Kollegen, Freunden und Schülern, Göttingen: Vandenhoeck \& Ruprecht, 579-591.

Markham, Clements Robert (1862), Travels in Peru and India [...], London: John Murray.

Melzer, Gudrun (2014), 'A Palaeographic Study of a Buddhist Manuscript from the Gilgit Region: A Glimpse into a Scribes' Workshop', in Quenzer, Bondarev and Sobisch (eds) 2014, 227-272.

More, J. B. Prashant (2004), Muslim Identity, Print Culture, and the Dravidian Factor in Tamil Nadu, New Delhi: Orient Longman. 
Morey, Stephen (2015), 'Metadata and endangered archives: lessons from the Ahom Manuscripts Project', in Maja Kominko (ed.), From Dust to Digital: Ten Years of the Endangered Archives Programme, Cambridge [UK]: Open Book Publishers, 31-65.

Nakatani, H. (1987), Udānavarga de Subaši: édition critique du manuscrit sanskrit sur bois provenant de Subaši, Bibliothèque nationale de Paris, Fonds Pelliot (Publications de l'Institut de civilisation indienne, 53-54), 2 vols, Paris: Collège de France, Institut de civilisation indienne.

O'Hanlon, Rosalind, Anand Venkatkrishnan and Richard David Williams (2020), 'Scribal service people in motion: Culture, power and the politics of mobility in India's long eighteenth century, c. 1680-1820', The Indian Economic and Social History Review, 57/4: 443-460.

Pelliot, Paul (tr.) (1902), Mémoires sur les coutumes du Cambodge de Tcheou Ta-Kouan, Hanoi: F.-H. Schneider.

Perilli, Lorenzo (2006), 'Sache und Methode: Was hat Gottfried Hermann tatsächlich gesagt', Hermes, 134/1: 125-126.

Pipatchartlearnwong, Kwanjai, Akarapong Swatdipong, Supachai Vuttipongchaikij and Somsak Apisitwanich (2017), 'Genetic evidence of multiple invasions and a small number of founders of Asian Palmyra palm (Borassus flabellifer) in Thailand', BMC Genetics, 18/88: 1-8.

Pollock, Sheldon (2007), 'Literary Culture and Manuscript Culture in Precolonial India', in Simon Eliot, Andrew Nash and Ian Willison (eds), Literary Cultures and the Material Book (British Library studies in the history of the book), London: British Library, 77-94.

Quenzer, Jörg, Dmitry Bondarev and Jan-Ulrich Sobisch (eds) (2014), Manuscript cultures: Mapping the field (Studies in manuscript cultures, 1), Berlin: De Gruyter.

Rath, Saraju (ed.) (2012), Aspects of Manuscript Culture in South India (Brill's Indological Library, 40), Leiden: Brill.

Rocher, Rosane and Ludo Rocher (2012), The Making of Western Indology: Henry Thomas Colebrooke and the East India Company (Royal Asiatic Society books), London: Routledge.

Ruiz-Falqués, Aleix (2014), 'Pali Literature: From Orality to Written Text', in Mark Elliott, Hildegard Diemberger and Michela Clemente (eds), Buddha's Word: The Life of Books in Tibet and Beyond, Cambridge: Museum of Archaeology and Anthropology University of Cambridge, 27-33.

Salomon, Richard (2014), 'Gāndhārī Manuscripts in the British Library, Schøyen and Other Collections', in Harrison and Hartmann (eds) 2014, 1-18.

Sander, Lore (1991), 'The Earliest Manuscripts from Central Asia and the Sarvāstivāda Mission', in Ronald E. Emmerick and Dieter Weber (eds), Corolla Iranica: Papers in Honour of Prof. Dr. David Neil MacKenzie on the Occasion of His 65th Birthday on April 8th, 1991, Frankfurt am Main: Peter Lang, 133-150.

Sander, Lore (2014), 'Dating and Localizing Undated Manuscripts', in Harrison and Hartmann (eds) 2014, 171-186.

Scherrer-Schaub, Cristina (2016), 'Printing versus Manuscript: History or Rhetoric? A Short Note Inspired by Pelliot DIC', in Diemberger, Ehrhard and Kornicki (eds) 2016, 153-170.

Sharshon, Tsering Dawa (2016), 'Continuity and New Developments in 15th Century Tibetan Book Production: Bo dong Phyogs las rnam rgyal (1376-1451) and His Disciples as Producers of Manuscript and Print Editions', in Diemberger, Ehrhard and Kornicki (eds) 2016, 237-266. 
Shaw, Graham (2009), 'South Asia', in Simon Eliot and Jonathan Rose (eds), A Companion to the History of the Book (Blackwell companions to literature and culture, 102), Chichester: Wiley-Blackwell, 126-137.

Sircar, Dinesh Chandra (1965), Indian Epigraphy, Delhi: Motilal Banarsidass.

Stein, Aurel (1928a), Innermost Asia: detailed report of explorations in Central Asia, Kan-su and eastern İān, carried out and described under the orders of H.M. Indian government, vol. 2 (text), Oxford: Clarendon.

Stein, Aurel (1928b), Innermost Asia : detailed report of explorations in Central Asia, Kan-su and eastern İān, carried out and described under the orders of H.M. Indian government, vol. 3 (plates and plans), Oxford: Clarendon.

Sweetman, Will and R. Ilakkuvan (ed. and tr.) (2012), Bibliotheca Malabarica: Bartholomäus Ziegenbalg's Tamil Library (Collection Indologie, 119), Pondicherry: Institut Français de Pondichéry / École française d'Extrême-Orient.

van der Meij, Dick (2017), Indonesian Manuscripts from the Islands of Java, Madura, Bali and Lombok (Handbook of Oriental Studies. Section 3 Southeast Asia, 24), Leiden: Brill.

van der Meij, Dick (forthcoming), 'Colophons in palm-leaf manuscripts from Bali and Lombok, Indonesia', in Nalini Balbir, Giovanni Ciotti and Martin Delhey (eds), The Syntax of Indic Colophons (provisional title).

von Hinüber, Oskar (2014), 'The Gilgit Manuscripts: An Ancient Buddhist Library in Modern Research', in Harrison and Hartmann (eds) 2014, 79-136.

Wallace, Vesna A. (2009), 'Diverse aspects of the Mongolian Buddhist manuscript culture and realms of its influence', in Berkwitz, Schober and Brown (eds), 2016, 76-94. 
